\title{
A Comprehensive Study on Provesicular Drug Delivery System: Proniosomal Gel
}

\author{
SANGEETHA GOVINDARAJAN ${ }^{*}$, M. SWAMIVELMANICKAM ${ }^{1}$, S. P. NAIR ${ }^{2}$, S. SIVAGNANAM ${ }^{1}$ \\ Department of Pharmaceutics, Krupanidhi College of Pharmacy, Bangalore 560035, ${ }^{1}$ Department of Pharmacy, Annamalai \\ University, Chidambaram 608002, ${ }^{2}$ Accenture, Bangalore 560029, India
}

\section{Govindarajan et al.: Provesicular Drug Delivery System}

\begin{abstract}
Vesicular approaches are novel techniques for transporting the drug that reinforces the availability of drugs and gives an action for a prolonged time. Besides, it has definite advantages over traditional drug delivery systems. Liposomes and niosomes comprising vesicles demonstrate the stability issues such as aggregation, leakage, fusion and sedimentation of vesicles due to the aqueous nature of the system. The provesicular system developed to overcome these problems for a unique novel approach includes proliposomes and proniosomes. Provesicles are dry, anhydrous formulations, coated with a non-ionic surfactant, acts as a carrier mixed with water when needed. This article reviews provesicular drug delivery systems with a focus on composition, preparation, the mechanism of drug delivery, encapsulation of the drug into provesicles and characterization techniques. Likewise, this review details the summary of research findings and patent reports on proniosomal investigations. As supported by the literature study, the proniosomes are a leading carrier for the delivery of various drugs over different routes of administration.
\end{abstract}

Key words: Provesicles, proniosomes, novel drug delivery, nonionic surfactant, transdermal drug delivery, toxicity

The primary goal of a provesicular approach is to sustain the drug release therapeutically with minimal adverse effects and allows drug transport with the help of drug carriers. Proniosomal drug delivery systems have acquired tremendous attention in the field of novel drug delivery. Proniosomal drug delivery systems have progressed into a range of drugs used commonly for several purposes, like the controlled release, prolonged release, drug targeting, improved drug permeation and localized action ${ }^{[1,2]}$.

Proniosomal drug delivery systems can entangle both hydrophilic and hydrophobic drugs by encapsulation and partitioning systems between hydrophobic domains, based on the size and number of the bilayer ${ }^{[3]}$. Today, various novel drug delivery techniques have emerged to accomplish either controlled or targeted delivery, covering different routes of drug administration. Vesicular drug delivery is an innovative technique that encapsulates and ensures the targeted delivery of drugs like liposomes, noisome, transferosomes, pharmacosomes and provesicles ${ }^{[4]}$.

Amongst all the vesicles, lipid vesicle carrier i.e., liposomes has gained great significance due to the

*Address for correspondence

E-mail: sange2008@gmail.com

January-February 2022 encapsulation of various types of drugs. The primary restrictions in the use of liposomes are physical and chemical issues of stability. Niosomes, also is known as non-ionic surfactant carriers, are a great substitute to liposomes. Niosomes have similar physical properties as that of liposomes. Niosomes mostly contain cholesterol and made up of non-ionic surfactants. Niosomes also have physical stability issues such as fusion, aggregation, sedimentation on storage and leakage of entrapped drugs on storage, all of which limit their shelf life $\mathrm{e}^{[5-8]}$.

To overcome the above-said problems associated with the traditional vesicles, a possible and the most recent method to construct physically and chemically stable vesicles is a provesicular carrier system called proniosomes. Proniosomes is a carrier obtained from hydrated mixtures of cholesterol and a nonionic surfactant ${ }^{[9,10]}$.

This is an open access article distributed under the terms of the Creative Commons Attribution-NonCommercial-ShareAlike 3.0 License, which allows others to remix, tweak, and build upon the work non-commercially, as long as the author is credited and the new creations are licensed under the identical terms

Accepted 03 January 2022

Revised 19 August 2021

Received 29 April 2020

Indian J Pharm Sci 2022;84(1):1-13 


\section{PRONIOSOMES}

Proniosomes, also referred to as dry niosomes provides the extra advantage of transport, distribution, storage and dosing, thus making makes them a prominent novel drug delivery system. Proniosomes is an anhydrous, free-flowing, water-soluble carrier that is coated with surfactant and can form niosomal dispersion on subsequent hydration with warm water. For transdermal drug delivery, proniosomes is excellent vesicular drug delivery systems because they function as a drug depot for an extended period and increases skin permeation. Proniosomal gel is a clear, liquid lamellar crystal of vesicular bilayer. It is formed by the addition of a small amount of gel-forming agent or water to the dry proniosomes mix of a non-ionic surfactant, lecithin and cholesterol. Proniosomal gel is more predominant due to the right sort of solicitation and superior absorption through skin compared to other semi-solid preparations ${ }^{[11-13]}$.

\section{Merits and demerits:}

Proniosomes does not demand any unique environments for storage conditions. They are substantially stable in comparison to niosomes and elementary to handle, store and transport. They are clear in practice since it will be hydrated only just before use. Proniosomes is dimensionally identical. Also, proniosomal preparations avoid inappropriate solvents. Besides, it can build up as transdermal patches. Proniosomes does not cause the distribution of vesicles into the polymeric materials ${ }^{[14,15]}$. No substantial stability issues like clumps, aggregation, sedimentation and leakage during storage ${ }^{[16]}$. Proniosomes offered enhanced bioavailability with lesser side effects and encapsulated with water-soluble and lipid-soluble drugs. Proniosomes is the harmonious carrier with the ideal property of decomposable, compatible with the $\operatorname{skin}^{[17]}$. Proniosomes is a flexible drug delivery system formulated with a broad range of drugs and a potential number of active constituents.

\section{Drug transport through the skin:}

The research study carried out on the transdermal application of provesicles, the results are inconsistent. The variables that affect the vesicle skin interactions are not evident, but entrust the remarkable part of evaluating the effectiveness of drug transport through the skin. If a drug loaded in proniosomes for the release of the drug, it should be hydrated to form niosomes. Many researchers proposed various theories and mechanisms employed in vesicle-skin interaction. There are two types of vesicle-skin communications observed ${ }^{[18,19]}$. When the vesicles reach stratum corneum, it forms aggregates and adheres to the skin. Thermodynamic activity between the vesicles and corneum drives the permeation of fat soluble drugs through the corneum. The above interaction encompasses structural modifications in the legitimate character of the skin, particularly in the intercellular lipid sections, at a depth of about $10 \mathrm{~mm}$, as shown by Freeze Fracture Electron Microscopy (FFEM) and Small Angle X-ray Scattering (SAXS). Additionally, the vesicles act as a carrier for drug transport. The drug transport is controlled by the lamellar formation of niosomes; functions as a ratelimiting barrier for drug release ${ }^{[20]}$.

\section{Formation of niosomes from proniosomes:}

Proniosomes transforms into niosomes upon hydration and assembles numerous multilayer vesicles. Hydration occurs either by hydrates occurs in the skin or by aqueous or aqueous-based solutions. Proniosomes encapsulates both hydrophilic and hydrophobic drugs ${ }^{[21]}$. Niosomes can be prepared experimentally through proniosomes, including an aqueous phase of the drug to proniosomes. The mean phase transition temperature of surfactant and agitations controlled during hydration ${ }^{[22-25]}$. The formation of niosomes from proniosomes is shown in fig. 1.

\section{COMPONENTS AND ITS EFFECT ON PRO- NIOSOMES}

Proniosomal gel comprises various ingredients such as surfactants, phosphatidylcholine, cholesterol, alcohol and aqueous phase.

\section{Surfactants:}

Nonionic surfactants are the best choice of surfactants for the preparation of proniosomes and since it possesses the ability to enhance solubility, which helps in increasing the bioavailability of less watersoluble drugs ${ }^{[26]}$. A recent study reported that nonionic surfactants enhance the bioavailability of acyclovir and griseofulvin ${ }^{[27,28]}$. The choice of surfactant implies on entrapment efficiency and the vesicle size of drugs, which in turn depends on Hydrophilic Lipophilic Balance (HLB) value, chemical nature and phase Critical Temperature $\left(T_{c}\right)$. Besides, the chain length of the surfactant and the size of the hydrophilic group define entrapment efficiency. The surfactant falls the HLB valve between 14-17, does not appropriate for the preparation of niosomes, whereas the HLB value of 8.6 produces niosomes with maximum entrapment 


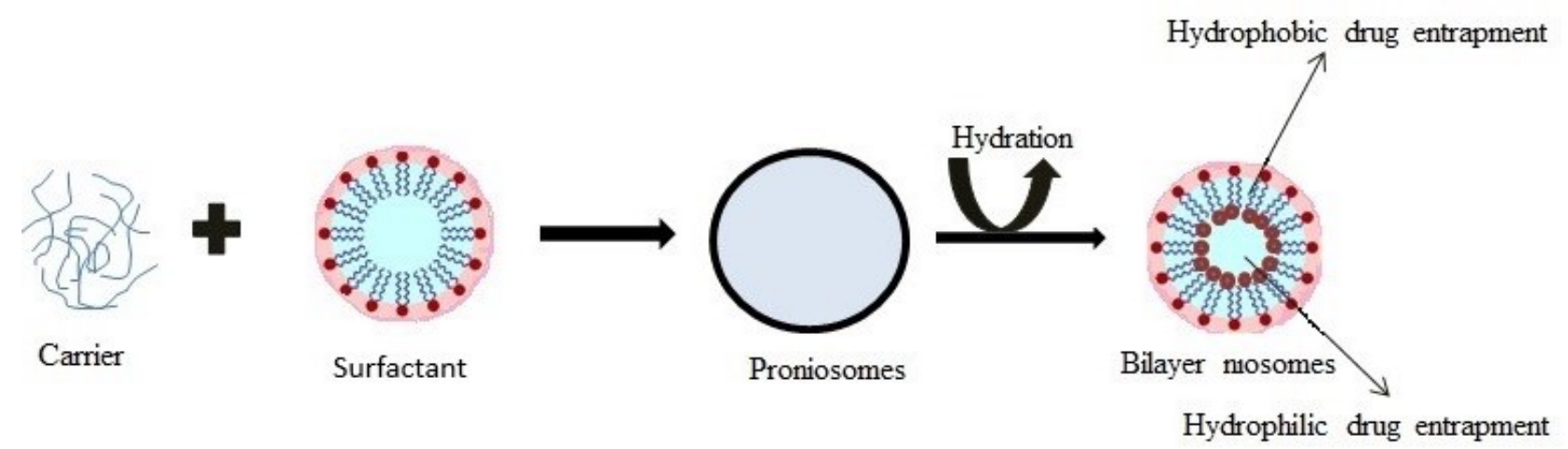

Fig. 1: Formation of niosomes from proniosomes

efficiency. If the HLB value of the surfactant is lower than 6 , the addition of cholesterol to the surfactant enhances the encapsulation efficiency and the stability of the vesicles. Due to the hydrophobic nature of cholesterol, it moderates the aggregation and structures lipid bilayer with excellent stability ${ }^{[29]}$. Cholesterol and surfactant concentration in a 1:1 ratio proved to produce excellent entrapment efficiency ${ }^{[30]}$. However, the HLB value of surfactant between 4 to 8 , reported being applicable for vesicle formation ${ }^{[31]}$. HLB values of different surfactants are illustrated in Table 1.

The alkyl chain length is under a direct and the proportionate effect on phase transition temperature, entrapment efficiency and the formation of an orderly gel. The longer the alkyl chain length of surfactant higher the entrapment efficiency. Furthermore, high phase transition temperature, it forms a high orderly gel and less leakage of the vesicle ${ }^{[32]}$.

\section{Phosphatidylcholine:}

Phosphatidylcholine is a phospholipid and it extracted from lecithin. The frequently utilized lecithin is the soya lecithin, a source of soya beans and the egg lecithin source of egg yolk. The solubility of lecithin is generally low in the water. In aqueous solution, lecithin can form liposomes, micelles or lamellar arrangements being dependent on hydration and temperature. In the preparation of proniosomal gel, lecithin acts as a permeation enhancer and it intensifies the portion of drug entrapment properties to the elevated phase transition temperature. Soya lecithin enhances the permeation of drugs and is also serving as a stabilizing agent ${ }^{[33,34]}$. It has found vesicle containing soya lecithin has a greater vesicle size than egg lecithin may be resulting from the divergence of the intrinsic structure ${ }^{[34]}$. A previous study reported that complexation of boswellic acid with phosphatidylcholine results, in terms of the better absorption and improved bioavailability ${ }^{[35]}$.

\section{Cholesterol:}

Cholesterol is an essential component in the preparation of proniosomes. Cholesterol imparts stability and permeability to the vesicles. The quantity of drugs entrapped in the proniosomes depends on the concentration of cholesterol utilized and higher transition temperature of span $60^{[36]}$. Similarly, noted that too high cholesterol content had a diminishing result of drug entrapment of the vesicles. The fact of that cholesterol might be after a peculiar level competes with the drug to orientate areas within the lipid bilayer. The removal of drugs from the bilayer leading to loss of drug entrapment ${ }^{[31]}$.

\section{Solvents:}

The choice of solvents is also a crucial factor, which significantly impacts the vesicle size and drug permeation. The literature study showed that, based on the phase separation and solubility of alcohol in water, the size of vesicles increases in the following order ${ }^{[37]}$, ethanol $>$ propanol $>$ butanol $>$ isopropanol. The choice of solvent also affects the intuitive of the formation of niosome. A formulation containing isopropanol and butanol was developed more spontaneously due to faster phase separation than niosomes consisting of propanol and ethanol, due to their lower solubility in water $^{[38]}$.

\section{Aqueous phase:}

The extensively used aqueous phases in the formulation of proniosomes are hot water, $0.1 \%$ glycerol and phosphate buffer $\mathrm{pH}$ 7.4. The $\mathrm{pH}$ of the aqueous phase is a critical factor that defines the entrapment of drugs ${ }^{[39]}$. The components and their functions indicated in Table 2.

Drug selection: The criteria for drug selection of proniosomal gel on the presumption that drugs with 
low water solubility, high dosing frequency, short half-life and having adverse drug reactions are suitable for controlled drug delivery ${ }^{[40]}$. Entrapment of drugs into niosome increases the size of vesicles through interaction with surfactant head groups. These interactions increase the charge and mutual repulsion of the bilayer and lead to an increase in vesicle size ${ }^{[41]}$.

\section{TYPES OF PRONIOSOMES}

Proniosomes is classified in accordance with the kind of carrier used and the method of preparation. The types of proniosomes detailed shown in fig. 2.

\section{Dry granular proniosomes:}

Sorbitol based proniosomes: Sorbitol based proniosomes is dry preparation, which contains sorbitol as a carrier. It can be prepared by coating vesicles with non-ionic surfactants. Sorbitol based proniosomes made by slowly spraying the mix of surfactant and solvent with sorbitol powder and further evaporating the solution ${ }^{[16]}$.

Maltodextrin based proniosomes: Maltodextrin based proniosomes made by the fast slurry method. The time is taken to form proniosomes not influenced by the ratio of surfactant concentration to carrier ratio. Maltodextrin based proniosomes prepared by using more surfactants to carrier ratio. Preparation of proniosomes with sorbitol, gives rise to the forming of concrete surfactant cake. However, maltodextrin based proniosomes contains a greater surfactant resulting in a thin surface coating so that the rehydration process is simple ${ }^{[22]}$.

\section{Liquid crystalline proniosomes:}

During the interaction between surfactant and water, there are three means under which lipophilic chains of the surfactants transformed into a disorganized liquefied state known as a lyotropic liquid crystalline state. The three ways are extending the temperature at kraft point, addition of solvent, which liquefies lipids and use of both temperature and solvent. The lamellar phase consists of a lipid bilayer set up with overlapping within the intervening aqueous layer. These structures provide a standard X-ray diffraction and thread like structures under a polarized microscope. Liquid crystalline proniosomes, also known as proniosomal gel functions as a drug reservoir for transdermal drug delivery systems ${ }^{[42]}$. The transdermal patch consists of aluminum foil as the support material, together with a plastic sheet of appropriate thickness, adhered to the foil. Proniosomal gel is placed uniformly on a plastic sheet covered by a mesh made up of nylon fabric. The advantages of liquid crystalline proniosomes noted the following, significantly stable, substantial entrapment efficiency, functionally penetration enhancer, easy to scale up (no lengthy procedure is involved) and bypass the use of inappropriate pharmaceutical ingredients ${ }^{[43]}$.

\section{PREPARATION OF PRONIOSOMES}

Proniosomal drug preparations primarily consist of nonionic surfactants, carriers and membrane stabilizers. Proniosomes comprises of a variety of components. The original parts are non-ionic surfactant, cholesterol or lecithin. Proniosomal formulations are prepared by below techniques:

\section{Coacervation phase separation method:}

Proniosomal gel is prepared by dissolving surfactants and other constituents in an organic solvent by heating and then adding a little hydration medium. The hydration medium makes it possible for the development of a gel instead of dispersion. An adequate quantity of surfactant, lecithin, cholesterol and the drug mixed with a solvent in a glass vial $(5 \mathrm{ml})$ and further heated by covering the glass vial at $60^{\circ}$ to $70^{\circ}$ for $5 \mathrm{~min}$ in a water bath or till the surfactant liquefied completely. Then, the aqueous phase should be added to the above mixture and kept for 2 min. The mix should be kept at room temperature until the dispersion gets transformed into a proniosomal gel ${ }^{[44]}$. This method is simplistic and rapid, so it does not require any specified equipment. Coacervation phase separation techniques adopted for gel preparation. This method is suitable in the case of minor quantity or smaller doses designed on the labscale $^{[43]}$.

\section{Slurry method:}

The slurry method is used to produce proniosomes using maltodextrin as a carrier. The time length for forming proniosomes was not influenced by the surfactant ratio to carrier ratio. The entire surfactant solution is added to the maltodextrin powder in a rotary evaporator. Then, the vacuum is applied to the rotary evaporator, till the dry and free-flowing powder is obtained ${ }^{[45]}$. The drug consisting of niosomes derived from proniosomes might be structured in a method, that almost nearly a similar traditional niosomes are structured i.e., absorbing the drug into the surfactant on them in advance, the solution is sprayed on the carrier (sorbitol, maltodextrin) or assimilation of drugs to the water solution used to hydrate the proniosomes ${ }^{[40]}$. The advantage of the slurry 


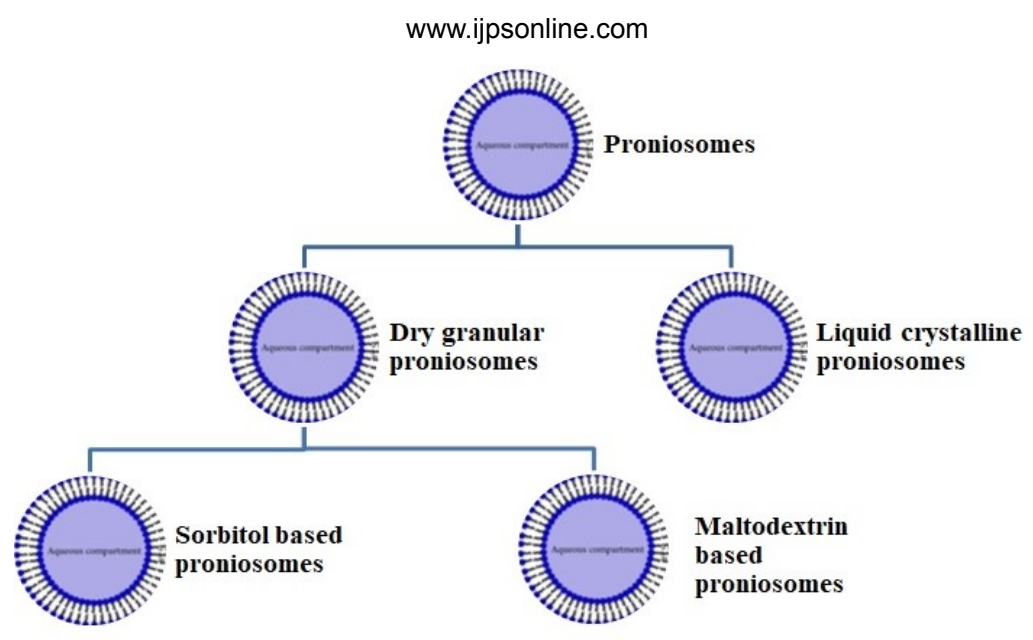

Fig. 2: Types of proniosomes

method is the use of maltodextrin, since maltodextrin is highly soluble in water, functions as a carrier. Due to the standardized coating on the carrier merely adding surfactant in an organic solvent, drug and surfactants are shielded from oxidation and hydrolysis. Demerits are time-consuming and the requirement of special equipment. This method can be used for fixed and batch size so that the product is repeatedly lost.

\section{Spray coated method:}

Spray coated method carried out by mixing the surfactant with the solvent and sprayed onto the carrier. Further, the solvent vaporized under the vacuum at $65^{\circ}$ to $70^{\circ}$ for 15 to $20 \mathrm{~min}$. This procedure continued until the carrier is loaded with sufficient surfactant since the surfactant coating on the carrier is so thin. The hydration of surfactant coated carriers enables multilamellar vesicles to be formed ${ }^{[46]}$. These proniosomes have similar vesicle size, comparable to those produced by typical methods. It is a smooth method ideal for lipophilic drugs without any issues of instability or susceptibility of the Active Pharmaceutical Ingredient (API) to hydrolysis. The demerit of the spray-coated method is the wear of carrier particles during the coating of the surfactant at a higher speed ${ }^{[47]}$.

\section{CHARACTERIZATION OF PRONIOSOMAL GEL}

\section{Physical appearance:}

Proniosomal gels must be observed under an optical microscope at 40x magnification for characterizing the color, physical condition and crystal characteristics of the drug ${ }^{[11]}$.

\section{Vesicle size distribution:}

Vesicle size is determined by hydration of vesicles with the phosphate buffer and followed by sonication. The dispersion observed under the optical microscope at 100 times magnification $^{[48]}$. A minimum of 200 vesicles determined under the microscope. The vesicle size and morphology were determined by Dynamic Light Scattering (DLS), Scanning Electron Microscopy (SEM), Transmission Electron Microscopy (TEM), Freeze-Fracture Electron Microscopy (F-FEM) and cryo- TEM.

\section{Measurement of $\mathrm{pH}$ :}

The $\mathrm{pH}$ of the proniosomal gel evaluated with the help of a digital $\mathrm{pH}$ meter. $100 \mathrm{mg}$ of proniosomal gel dispersed in $10 \mathrm{ml}$ of purified water and an electrode submerged into the proniosomal gel. The consistent reading noted. The $\mathrm{pH}$ examination needs to repeat three times ${ }^{[49]}$.

\section{Viscosity:}

The viscosity of proniosomal gel is commonly studied with the help of a Brookfield Viscometer with the use of a spindle at a temperature of $25 \pm 2^{\circ}$. Select the spindle and Revolutions Per Minute (RPM) on trial and error basis. The viscosity of proniosomal gel was determined by checking different spindle numbers at various speeds. The spindle and RPM, corresponding to the torque value between $20 \%$ to $100 \%$ preferred for the measurement of viscosity. The gel placed a jar and spindle set perpendicularly, ensures that the spindle does not touch the base of the jar. The viscosity of the proniosomal gel noted ${ }^{[50]}$.

\section{Zeta potential:}

Zeta potential can be verified by applying a Zetasizer or other methods and indicates the net charge on the 
surface of the proniosomes gel. Place proniosomal gel dispersion in a cell that contains two electrodes. When the voltage passed, the gel particles will move towards oppositely charged electrodes ${ }^{[11]}$. The higher net charge on the surface of vesicles generates a repulsive force between the vesicles. It makes the vesicles stable, no agglomeration and also helps faster sedimentation, giving a uniformly dispersed proniosomal gel. Proniosomal gel with zeta potential value of over \pm 30 $\mathrm{mV}$ considered stable formulation ${ }^{[52]}$.

\section{Drug entrapment efficiency:}

Entrapment efficiency calculated by distributing the proniosomal gel in phosphate buffer. The dispersed liquid is then centrifuged in an ultra-cooling centrifuge at $18000 \mathrm{RPM}$ for an $\mathrm{h}$ at $40^{\circ}$. The supernatant liquid removed and the sedimentation is diluted with a suitable solvent and the level of unentrapped drug in the preparation analyzed using spectroscopic methods ${ }^{[33]}$.

The below formula computes entrapment efficiency percentage,

Entrapment efficiency $(\%)=$ Amount of entrapped drug/ Amount of total drug $\times 100$

\section{In vitro drug release studies:}

In vitro release of drug loaded proniosomal gel examined using Franz diffusion cell. A dialysis cellophane membrane with a molecular weight of about $12000^{[49]}$ fixed in between the donor compartment and receptor compartment and the volume of the receptor compartment must be $30 \mathrm{ml}$. The area and size of the donor compartment should be $2.54 \mathrm{~cm}^{2}$ and $2 \mathrm{~cm}$ respectively. The weighed amount of proniosomal gel kept on the donor side of the dialysis membrane and a saline phosphate buffer solution $\mathrm{pH} 7.4$ to be placed as a receptor medium. The receptor compartment needs to be held in a water jacket to manage the temperature level of $37 \pm 0.50^{\circ}$. The required heat shall be maintained by using a thermostatic hot plate along with a magnetic stirrer. During the sampling time, samples are removed at different time intervals and the same quantity of receptor liquid introduced quickly in order to maintain sink condition. The collected samples analyzed for drug concentration using a spectrophotometer or HighPerformance Liquid Chromatography (HPLC) ${ }^{[54]}$.

\section{Skin permeation studies:}

The skin permeation study is performed using the skin of male Wister albino rats. The skin cleansed to get rid of the subcutaneous fat as well as various other blood vessels. Cut skin is kept in a deep freezer at $-20^{\circ}$ until it is used ${ }^{[55]}$. Before the experiment, the skin should be treated with saline phosphate buffer at $\mathrm{pH} 7.4$ for $1 \mathrm{~h}$ and then kept in between two compartments of a Franz diffusion cell. The stratum corneum and the dermis part of the skin should be stored in the donor and receptor compartment sides respectively. The matching conditions of in vitro release studies are replicated in the skin permeation study. The quantity of drug penetrated via the skin to the receptor medium can be analyzed with the help of a spectrophotometer or HPLC. This experiment should be performed three times ${ }^{[56]}$.

\section{Skin irritation test:}

The skin irritation test is crucial for the topical/ transdermal delivery of drugs. The test is performed using Wister albino rats weighing about 80 to $85 \mathrm{~g}$. The proniosomal gel is applied to the left ear of the albino rats and the standard irritant $(0.8 \%)$ formalin solution should be applied to the right ear. The tested skin checked for the level of sensitivity for a $\mathrm{w}$ and observations rated on a scale 0 to 4; 0 for no erythema/ edema, 1 for very slight erythema/edema, 2 for welldefined erythema/slight edema, 3 for moderate to severe erythema/moderate edema and 4 for severe erythema/edema formation as explained in Draize score method ${ }^{[57]}$.

\section{Stability studies:}

Stability studies can be done based on the International Conference for Harmonization (ICH) guidelines. The stability study is conducted for the proniosomal gel at a refrigeration temperature of $2^{\circ}$ to $8^{\circ}$, room temperature of $25 \pm 0.5^{\circ}$ and at an elevated temperature of $45 \pm 0.50^{\circ}$ for $90 \mathrm{~d}$. The proniosomal gel has taken out at regular intervals for the calculation of drug concentration and the average vesicle size. The gel is observed microscopically for modifications in the solid and liquid crystalline structure. Additionally, the proniosomal gel is examined for particle size as well as percentage drug entrapment ${ }^{[58]}$.

\section{TOXICITY OF PRONIOSOMES}

Both proniosomes and niosomes prepared with similar constituents. When the proniosomes are hydrated, it becomes niosomes. The toxicity of proniosomes is not specific since the research study reports are finite. The common component of proniosomes is a surfactant and cholesterol. The chemical nature of 
TABLE 1: SURFACTANTS AND HLB VALUE

\begin{tabular}{|c|c|c|c|c|}
\hline S. No & Non-ionic surfactant & Examples & HLB Value & Reference \\
\hline \multirow{4}{*}{1} & \multirow{4}{*}{ Sorbitan fatty acid esters } & Span 20-Sorbitan Monolaurate & 8.6 & \multirow{4}{*}{ [29] } \\
\hline & & Span 40-Sorbitan Monopalmitate & 6.7 & \\
\hline & & Span 60-Sorbiton Mono stearate & 4.7 & \\
\hline & & Span 80 -Sorbitan Mono oleate & 4.3 & \\
\hline \multirow{4}{*}{2} & \multirow{4}{*}{$\begin{array}{l}\text { Polyoxyethylene fatty acid } \\
\text { esters }\end{array}$} & Tween 20-Polyoxyethylene sorbitan mono laurate & 16.7 & \multirow{8}{*}{ [63] } \\
\hline & & Tween 40-Polyoxyethylene sorbitan mono palmitate & 15.6 & \\
\hline & & Tween 60-Polyoxyethylene sorbitan mono stearate & 14.9 & \\
\hline & & Tween 80-Polyoxyethylene sorbitan mono stearate & 15 & \\
\hline \multirow{5}{*}{3} & \multirow{4}{*}{$\begin{array}{c}\text { Alkyl ether and alkyl glyceryl } \\
\text { ethers }\end{array}$} & Brij 30-Polyoxyethylene(4) lauryl ether & 9.7 & \\
\hline & & Brij 35-Polyoxyethylene(23) lauryl ether & 16.9 & \\
\hline & & Brij 58-Polyoxyethylene(20) cetyl ether & 15.7 & \\
\hline & & Brij 92-Polyoxyethylene(2) oleyl ether & 4.9 & \\
\hline & Novel Non-ionic surfactant & Chemical Name & HLB value & Reference \\
\hline 4 & Kolliphore RH 40 & Polyoxyl 40- hydrogenated oil & $14-16$ & [64] \\
\hline 5 & Capmul MCM & Mono- and dicapric acid esters of glycerols & $5-6$ & [65] \\
\hline 6 & Labrafil M 1944 CS & Oleoyl macrogol-6glycerides & 9 & \\
\hline 7 & Labrafil M 2125 CS & Linoleoyl macrogol-6 glycerides & 9 & [66] \\
\hline 8 & Labrasol & Caprylocaproyl macrogol-8 glycerides & 12 & \\
\hline
\end{tabular}

TABLE 2: COMPONENTS OF PRONIOSOMAL GEL

\begin{tabular}{|c|c|c|c|}
\hline S. No & Ingredients used & Example & Use \\
\hline 1 & Surfactants (Non-ionic) & $\begin{array}{c}\text { Spans 20, 40, 60, 80, } 85 \\
\text { Tween 20,40,80 } \\
\text { Brij 35,93 } \\
\text { Cremophor RH } 40 \\
\text { Lutrol F68, } \\
\text { Labrafil M 1944 CS }\end{array}$ & Imparts in entrapment efficiency \\
\hline 2 & Cholesterol & cholesterol & $\begin{array}{l}\text { Imparts in rigidity and permeability of the } \\
\text { vesicles }\end{array}$ \\
\hline 3 & Lecithin & Soya/Egg lecithin & Penetration enhancer, membrane stabilizer \\
\hline 4 & Solvents & Ethanol, methanol, butanol, isopropanol & Imparts in the formation of vesicle size \\
\hline 5 & Carriers & Maltodextrin & Provides flexibility \\
\hline 6 & Aqueous phase & $\begin{array}{c}\text { Sorbitol } \\
\text { Water, } 0.1 \% \text { glycerol, } \\
\text { phosphate buffer pH } 7.4\end{array}$ & $\begin{array}{l}\text { Alters the drug distribution } \\
\text { For hydration }\end{array}$ \\
\hline
\end{tabular}

the surfactant imparts toxicity. It is evident that the ester derived surfactant is harmful compared to the ether; this may be because of enzymatic deterioration of the ester bonds. Despite the above-said toxicity issues, it does not have any significance in the form of the formulation, i.e., dry powders or gels ${ }^{[32]}$. Very less evident that the lomefloxacin proniosomes showed higher ocular toleration without causing any redness, swelling, or inflammation ${ }^{[59]}$. According to the research study, non-ionic surfactants damage the cornea, (Tables 3 and 4). conjunctive epithelium and causes ocular irritation, redness and swelling ${ }^{[60]}$. Another research study states that span 60 and cholesterol are the most preferred constituents for proniosomes. Cholesterol is the most choice because of the reason that it does not cause any ocular toxicity ${ }^{[61]}$. Therefore, the model recommends that non-ionic surfactant enclosed proniosomes does not produce ciliotoxicity through intranasal delivery and cytotoxicity when used through skin delivery ${ }^{[62]}$ 


\begin{tabular}{|c|c|c|c|c|c|c|c|c|c|}
\hline \multirow[b]{2}{*}{$\begin{array}{l}\text { S. } \\
\text { No }\end{array}$} & \multirow[b]{2}{*}{ Drug/Dose } & \multirow[b]{2}{*}{ Components } & \multirow[b]{2}{*}{ Method } & \multicolumn{4}{|c|}{ Research Reports } & \multirow[b]{2}{*}{ Application } & \multirow[b]{2}{*}{ Reference } \\
\hline & & & & $\begin{array}{l}\text { Vesicle } \\
\text { size }\end{array}$ & $\begin{array}{l}\text { Encapsulation } \\
\text { efficiency (\%) }\end{array}$ & $\begin{array}{c}\text { In vitro } \\
\text { drug } \\
\text { release } \\
(\%)\end{array}$ & $\begin{array}{c}\text { Ex vivo } \\
\text { permeation } \\
\text { flux }(\mu \mathrm{g} / \\
\left.\mathrm{cm}^{2} / \mathrm{h}\right) / \text { Models } \\
\text { used }\end{array}$ & & \\
\hline 1 & $\begin{array}{l}\text { Doxorubicin } \\
\mathrm{Hcl}(100 \mathrm{mg})\end{array}$ & $\begin{array}{l}\text { Span 20, Span } \\
\text { 40, Span 60, } \\
\text { Span } 80 \\
\text { Maltodextrin }\end{array}$ & $\begin{array}{l}\text { Slurry } \\
\text { method }\end{array}$ & $\begin{array}{c}4.8-5.2 \\
\mu \mathrm{m}\end{array}$ & $\begin{array}{l}84.88 \\
\pm 0.14\end{array}$ & $\begin{array}{l}95.19 \\
\pm 0.20 \\
(36 \mathrm{~h})\end{array}$ & - & $\begin{array}{c}\text { Anti-cancer } \\
\text { agent }\end{array}$ & [67] \\
\hline 2 & $\begin{array}{l}\text { Lornoxicam } \\
\qquad(5 \mathrm{mg})\end{array}$ & Span 60 & $\begin{array}{l}\text { Coaservation } \\
\text { Phase } \\
\text { separation } \\
\text { method }\end{array}$ & $\begin{array}{c}485.08 \\
\pm 24.12 \mathrm{~nm}\end{array}$ & $\begin{array}{l}92.33 \\
\pm 2.37\end{array}$ & $\begin{array}{l}40.69 \\
\pm 3.02 \\
(25 \mathrm{~h})\end{array}$ & $\begin{array}{c}52.15 \\
\text { (Rat skin) }\end{array}$ & NSAID & [68] \\
\hline 3 & $\begin{array}{l}\text { Fluconazole } \\
\text { (50 mg) }\end{array}$ & $\begin{array}{l}\text { Span 20, } \\
\text { Span 60, } \\
\text { Tween } 80\end{array}$ & $\begin{array}{l}\text { Coaservation } \\
\text { Phase } \\
\text { separation } \\
\text { method }\end{array}$ & $\begin{array}{c}25.41 \\
\pm 0.51 \mathrm{~nm}\end{array}$ & $\begin{array}{l}97.66 \\
\pm 1.24\end{array}$ & $\begin{array}{c}4.52 \\
\pm 8.25 \\
(6 \mathrm{~h})\end{array}$ & - & $\begin{array}{c}\text { Anti } \\
\text {-fungal }\end{array}$ & [49] \\
\hline 4 & $\begin{array}{l}\text { Ethiny- } \\
\text { lestradiol } \\
\text { and Levonor- } \\
\text { gesterel } \\
(10 \mathrm{mg})\end{array}$ & Span 20 & $\begin{array}{l}\text { Coaservation } \\
\text { Phase } \\
\text { separation } \\
\text { method }\end{array}$ & $385.4 \mathrm{~nm}$ & $\begin{array}{l}86.85 \\
\pm 0.85\end{array}$ & $\begin{array}{l}86.42 \\
\pm 0.61 \\
(24 \mathrm{~h})\end{array}$ & - & $\begin{array}{c}\text { Anti } \\
\text {-fertility }\end{array}$ & [69] \\
\hline 5 & Duloxetine & $\begin{array}{l}\text { Tween 80, } \\
\text { Chitosan }\end{array}$ & $\begin{array}{l}\text { Coaservation } \\
\text { Phase } \\
\text { separation } \\
\text { method }\end{array}$ & $\begin{array}{c}223.9 \\
\pm 11.07 \mathrm{~nm}\end{array}$ & $\begin{array}{l}76.21 \\
\pm 1.24\end{array}$ & $\begin{array}{l}74.71 \\
(8 \mathrm{~h})\end{array}$ & $\begin{array}{l}\text { 16.1/ Goat } \\
\text { mucosa } \\
\text { (Drug loaded } \\
\text { mucoadhesive } \\
\text { proniosomal } \\
\text { gel has } \\
\text { shown } 1.86 \\
\text { fold higher } \\
\text { than the } \\
\text { drug loaded } \\
\text { proniosomal } \\
\text { gel) }\end{array}$ & $\begin{array}{c}\text { Anti } \\
\text {-depressant }\end{array}$ & [70] \\
\hline 6 & $\begin{array}{l}\text { Brimonidine } \\
\text { tartrate }\end{array}$ & $\begin{array}{l}\text { Span 60, } \\
\text { Tween } 80\end{array}$ & $\begin{array}{l}\text { Coaservation } \\
\text { Phase } \\
\text { separation } \\
\text { method }\end{array}$ & $\begin{array}{c}810 \\
\pm 16.75 \mathrm{~nm}\end{array}$ & $\begin{array}{l}79.23 \\
\pm 1.12\end{array}$ & $\begin{array}{l}91.11 \\
\pm 1.76 \\
(24 \mathrm{~h})\end{array}$ & - & $\begin{array}{c}\text { Treatment } \\
\text { of } \\
\text { glaucoma }\end{array}$ & [53] \\
\hline 7 & $\begin{array}{l}\text { Tramadol } \\
(100 \text { mg) }\end{array}$ & $\begin{array}{c}\text { Span 20, Span } \\
\text { 40, Span 60, } \\
\text { Span 80, } \\
\text { Tween 20, } \\
\text { Tween 40, } \\
\text { Tween 60, } \\
\text { Tween } 80\end{array}$ & $\begin{array}{l}\text { Coaservation } \\
\text { Phase } \\
\text { separation } \\
\text { method }\end{array}$ & $\begin{array}{c}121.73 \\
\pm 64.53 \mathrm{~nm}\end{array}$ & $\begin{array}{r}89.9 \\
\pm 3.71\end{array}$ & $\begin{array}{l}59.65 \\
\pm 2.1 \\
(24 \mathrm{~h})\end{array}$ & $\begin{array}{c}95.09 \\
\text { (Rat skin } \\
\text { membrane) }\end{array}$ & $\begin{array}{c}\text { Opioid } \\
\text { analgesic }\end{array}$ & [55] \\
\hline 8 & $\begin{array}{l}\text { Neomycin } \\
\text { sulphate } \\
(5 \mathrm{mg})\end{array}$ & Span 60 & $\begin{array}{l}\text { Coaservation } \\
\text { Phase } \\
\text { separation } \\
\text { method }\end{array}$ & $\begin{array}{c}404 . \\
\pm 0.02 \mathrm{~nm}\end{array}$ & $\begin{array}{l}77.96 \\
\pm 0.06\end{array}$ & $\begin{array}{l}78.39 \\
\pm 0.05 \\
(24 \mathrm{~h})\end{array}$ & $\begin{array}{c}63.76 \\
\pm 0.01 \% \\
(24 \mathrm{~h}) \\
\text { Human } \\
\text { cadaver skin }\end{array}$ & $\begin{array}{l}\text { Amino- } \\
\text { glycosides } \\
\text { antibiotic }\end{array}$ & [71] \\
\hline 9 & $\begin{array}{l}\text { Aceclofenac } \\
\text { (100 mg) }\end{array}$ & $\begin{array}{c}\text { Span 60, } \\
\text { Maltodextrin, } \\
\text { Glucose, } \\
\text { Mannitol }\end{array}$ & $\begin{array}{l}\text { Slurry } \\
\text { method }\end{array}$ & $4-6 \mu \mathrm{m}$ & $84 \pm 1$ & -- & -- & NSAID & [72] \\
\hline
\end{tabular}




\begin{tabular}{|c|c|c|c|c|c|c|c|c|c|}
\hline 10 & Atenolol & $\begin{array}{c}\text { Span 20, Span } \\
\text { 40, Span } 60 \\
\text { Span } 80\end{array}$ & $\begin{array}{l}\text { Coaservation } \\
\text { Phase } \\
\text { separation } \\
\text { method }\end{array}$ & -- & $\begin{array}{c}99.21 \\
\pm 0.3\end{array}$ & $\begin{array}{l}99.14 \\
(24 \mathrm{~h})\end{array}$ & $\begin{array}{l}\text { Male albino } \\
\text { rat, } \\
\text { Shed snake } \\
\text { skin, } \\
\text { Male guinea } \\
\text { pig }\end{array}$ & $\begin{array}{c}\text { Anti-hyper- } \\
\text { tensive }\end{array}$ & [54] \\
\hline 11 & $\begin{array}{l}\text { Fluconazole } \\
\text { (100 mg) }\end{array}$ & $\begin{array}{c}\text { Span 20, Span } \\
60, \text { Span } 80\end{array}$ & $\begin{array}{l}\text { Coaservation } \\
\text { Phase } \\
\text { separation } \\
\text { method }\end{array}$ & $2.6 \mu \mathrm{m}$ & 96.1 & $\begin{array}{l}77.8 \\
(3 \mathrm{~h})\end{array}$ & $\begin{array}{l}394.09 \\
(3 \mathrm{~h}) \\
\text { Oral goat } \\
\text { mucosa }\end{array}$ & Antifungal & {$[73]$} \\
\hline 12 & $\begin{array}{l}\text { Aceclofenac } \\
\quad(10 \mathrm{mg})\end{array}$ & $\begin{array}{c}\text { Span } 20, \\
\text { Span } 40 \text { Span } \\
60, \text { Span } 80\end{array}$ & $\begin{array}{l}\text { Coaservation } \\
\text { Phase } \\
\text { separation } \\
\text { method }\end{array}$ & $\begin{array}{c}136-236 \\
\mu \mathrm{m}\end{array}$ & $\begin{array}{l}97.60 \\
\pm 1.85\end{array}$ & $\begin{array}{c}99.8 \\
(14 \mathrm{~h})\end{array}$ & $\begin{array}{c}230 \\
(24 \mathrm{~h}) \\
\text { Oral } \\
\text { mucosa }\end{array}$ & $\begin{array}{c}\text { Treatment } \\
\text { of oro- } \\
\text { dental } \\
\text { ailments }\end{array}$ & [74] \\
\hline 13 & Itraconazole & $\begin{array}{l}\text { Span 60, } \\
\text { Brij } 35\end{array}$ & $\begin{array}{l}\text { Coaservation } \\
\text { Phase } \\
\text { separation } \\
\text { method }\end{array}$ & $\begin{array}{c}286.67 \\
\pm 0.588 \\
-697.5 \\
\pm 0.834 \mathrm{~nm}\end{array}$ & $\begin{array}{c}78.56 \\
-95.46\end{array}$ & $\begin{array}{c}97.8 \\
(24 \mathrm{~h})\end{array}$ & - & Anti-fungal & {$[75]$} \\
\hline 14 & $\begin{array}{l}\text { Atorvastatin } \\
\quad(10 \mathrm{mg})\end{array}$ & Span 60 & $\begin{array}{l}\text { Coaservation } \\
\text { Phase } \\
\text { separation } \\
\text { method }\end{array}$ & $\begin{array}{c}65.72 \\
\pm 2.12 \mathrm{~nm}\end{array}$ & $\begin{array}{l}97.42 \\
\pm 0.37\end{array}$ & $\begin{array}{l}99.72 \\
(24 \mathrm{~h})\end{array}$ & $\begin{array}{c}193.754 \\
\pm 3.126 \\
\text { Male } \\
\text { Wister } \\
\text { rat skin }\end{array}$ & $\begin{array}{c}\text { Treatment } \\
\text { of hype } \\
\text { rlipidemia }\end{array}$ & {$[76]$} \\
\hline 15 & $\begin{array}{c}\text { Tenofovir } \\
\text { Disoproxil } \\
\text { fumarate (10 } \\
\mathrm{mg})\end{array}$ & $\begin{array}{c}\text { Span } 20, \\
\text { Span } 40 \text { Span } \\
60, \text { Span } 80, \\
\text { Tween } 20, \\
\text { Tween } 80\end{array}$ & $\begin{array}{l}\text { Coaservation } \\
\text { Phase } \\
\text { separation } \\
\text { method }\end{array}$ & $\begin{array}{c}2.96 \\
-10.91 \mu \mathrm{m}\end{array}$ & 70.6 & $\begin{array}{c}92.2 \\
(24 \mathrm{~h})\end{array}$ & $\begin{array}{c}82.4 \\
(24 \mathrm{~h}) \\
\text { Goat } \\
\text { vaginal } \\
\text { mucosa }\end{array}$ & $\begin{array}{c}\text { Anti } \\
\text {-retroviral }\end{array}$ & [30] \\
\hline 16 & Ofloxacin & $\begin{array}{c}\text { Span 60, } \\
\text { Maltodextrin }\end{array}$ & $\begin{array}{l}\text { Slurry } \\
\text { method }\end{array}$ & $\begin{array}{c}409.2 \\
\pm 2.28 \mathrm{~nm}\end{array}$ & $\begin{array}{l}87.16 \\
\pm 1.21\end{array}$ & $\begin{array}{l}86.35 \\
(12 \mathrm{~h})\end{array}$ & -- & $\begin{array}{l}\text { Broad } \\
\text { spectrum } \\
\text { antibiotic }\end{array}$ & {$[77]$} \\
\hline 17 & $\begin{array}{c}\text { Dorzolamide } \\
\text { Hydrochloride } \\
\text { (40 mg) }\end{array}$ & Span 60 & $\begin{array}{l}\text { Coaservation } \\
\text { Phase } \\
\text { separation } \\
\text { method } \\
\end{array}$ & $\begin{array}{c}189.5 \\
\pm 35.76 \mathrm{~nm}\end{array}$ & $\begin{array}{l}84.5 \\
\pm 1.5\end{array}$ & $\begin{array}{c}58.51 \\
\pm 1.00 \\
(8 \mathrm{~h})\end{array}$ & -- & $\begin{array}{c}\text { Anti } \\
\text {-glaucoma }\end{array}$ & [78] \\
\hline
\end{tabular}

\section{TABLE 4: PATENT REPORTS ON PRONIOSOMAL RESEARCH}

\begin{tabular}{|c|c|c|c|c|c|}
\hline S. No & $\begin{array}{l}\text { Patent application } \\
\text { number and year }\end{array}$ & Inventor (s) & A drug used and field & Claims/Description of the work & Reference \\
\hline 1 & $\begin{array}{l}\text { CN103340823A } \\
\text { China (2015) }\end{array}$ & $\begin{array}{l}\text { Liu Qiang Jiang } \\
\text { Xiao, Liu Li, } \\
\text { Hu Hongxia, Li } \\
\text { Shasha Zhang } \\
\text { Bin }\end{array}$ & $\begin{array}{l}\text { The discovery discloses } \\
\text { the composition and } \\
\text { process of preparation } \\
\text { paeonol proniosomes } \\
\text { for the treatment of } \\
\text { rheumatic discomfort, } \\
\text { stomach pain and other } \\
\text { pain, eczema, allergic } \\
\text { dermatitis and other } \\
\text { diseases }\end{array}$ & $\begin{array}{l}\text { The present invention concerns } \\
\text { the field of pharmaceutical } \\
\text { formulations, in particular a novel } \\
\text { pharmaceutical carrier device of } \\
\text { nonionic paeonol and preparation } \\
\text { process. } \\
\text { The present discovery is } \\
\text { paeonol nonionic preparation, } \\
\text { measured as parts by weight of } \\
\text { the formulation containing the } \\
\text { following components: } 3 \sim 6 \text { parts } \\
\text { paeonol, } 64 \sim 145 \text { parts of a nonionic } \\
\text { surfactant, lecithin } 64 \sim 145 \text { parts } \\
\text { of cholesterol } 7 \sim 13 \text { parts, parts of } \\
\text { the organic phase, } 1-3 \text { parts of the } \\
\text { aqueous phase }\end{array}$ & [79] \\
\hline
\end{tabular}


2

US20190083461A1
United States

(2019)

3

WO2019038316A1 Umberto di Maio
WIPO (PCT) 2017 Um

WO2019038316A1 Umberto di Maio
WIPO (PCT) 2017

Susanne Krauss-

Etschmann Anton

Hartmann, Philippe

Schmitt-Kopplin, Michael Schloter
2 cells, such as allergy and in particular asthma

The present innovation concerns to D-tryptophan for use in the treatment, prevention or development of diseases related to regulatory $\mathrm{T}$ cells or T helper type formulation comprises a synergistic blend of vitamin $\mathrm{D}$, isoflavones and policosanols preferably, one, two or three additional components selected from boswellic acids, curcumin and vitamin $\mathrm{K}$ for the treatment of cardiovascular diseases, in particular for the reduction of vascular calcification and cholesterol levels and for increase of bone mineralization.
The embodiment of the present innovation comprises of one or more of the identified components of the group consisting of an orally acceptable carrier, sweeteners, colorants, preservatives, thickeners and stabilizers, anti-oxidants, color fixing agents etc.

Certain orally acceptable carriers are (biodegradable) liposomes; microspheres made of the biodegradable polymer Poly

(D,L)-Lactic-Glycolic Acid (PLGA), albumin microspheres; synthetic polymers (soluble); Nano fibers. Various carrier based dosage forms includes Solid Lipid Nanoparticles (SLNs), polymeric nanoparticles, ceramic nanoparticles, hydrogel nanoparticles, copolymerized peptide nanoparticles, nano crystals and nano suspensions, nano crystals, nanotubes and nanowires, functionalized nano carriers, nano spheres, nano capsules nano emulsions, etc.,

The present study claims that an increase in the bioavailability of boswellic acids is due to the use of proniosomes (dehydrated forms of niosomes), vesicles formed by non-ionic surfactants, which have a better penetration capability than other vesicles. The use of boswellic acids may be potentially useful for the prevention or treatment of vascular calcification.
[80]

\section{CONCLUSION}

In this study concluded that drugs, which are required for targeting, controlling the release, increase the solubility and permeation; vesicular drug delivery systems might be preferred impulsively and proniosomes received a firm endorsement in the field of drug delivery. Proniosomes is a flexible vesicular carrier with a variety of supremacy than the other carriers include liposomes and niosomes. Indeed, proniosomes has a potent role in transdermal drug delivery because of their increased penetration properties, non-toxicity and controlled drug release properties. Extensive proniosomal research is explicit that this methodology is challenging. Until this time, only a few types of drugs promoted. This might have been the shortfall of the literal industrial structure and perception of the provesicular drug delivery system. Enactment of the significant attention and evolution in provesicles will also inflate the new pharmaceutical classes of active molecules such as peptides, enzymes, genes and oligonucleotides.

\section{FUTURE}

Proniosomes is a resource for pharmaceutical research. The provesicular system has benefits over the vesicular system. Proniosomes is a reliable drug targeting system. Moreover, they provide the opportunity to impart more effective treatment than the prevailing drug delivery system. This needs to explore in the area of nutraceuticals, herbal products and cosmetics. 
The action of antibodies, peptides, vaccines, genes and sera is also a milestone in vesicular drug delivery. Notwithstanding that, most of the product types are right on the research level. Therefore, when implementing experiments for therapeutic applications, work must be carried out on the scale of the study in a pilot plant. Therefore, the development of industrial infrastructure for vesicular system needs to be installed to establish drug candidates into a vesicular system.

\section{Acknowledgements:}

We would like to express our great appreciation to Mr. S Thirumal valavan, Syngene International Ltd, Bangalore and Mr. T Mohan Kumar, Research scholar, Periyar University, Salem for their valuable support and proofread.

\section{Conflict of interests:}

The authors declared no conflicts of interest.

\section{REFERENCES}

1. Akhilesh D, Hazel G, Kamath JV. Proniosomes: A propitious provesicular drug carrier. Int $\mathrm{J}$ Pharm Pharm Sci Res 2011;1(3):98-103.

2. Mir M, Ishtiaq S, Rabia S, Khatoon M, Zeb A, Khan GM, et al. Nanotechnology: From in vivo imaging system to controlled drug delivery. Nanoscale Res Lett 2017;12(1):1-6.

3. Kamel R, Basha M, Abd El-Alim SH. Development of a novel vesicular system using a binary mixture of sorbitan monostearate and polyethylene glycol fatty acid esters for rectal delivery of rutin. J Liposome Res 2013;23(1):28-36.

4. Kakar R, Rao R, Goswami A, Nanda S, Saroha K. Proniosomes: An emerging vesicular system in drug delivery and cosmetics. Der Pharm Lett 2010;2(4):227-39.

5. El-Laithy HM, Shoukry O, Mahran LG. Novel sugar esters proniosomes for transdermal delivery of vinpocetine: Preclinical and clinical studies. Eur J Pharm Biopharm 2011;77(1):43-55.

6. Shaker DS, Nasr M, Mostafa M. Bioavailability and hypocholesterolemic effect of proniosomal simvastatin for transdermal delivery. Int J Pharm Pharm Sci 2013;5:344-51.

7. El Maghraby GM, Ahmed AA, Osman MA. Penetration enhancers in proniosomes as a new strategy for enhanced transdermal drug delivery. Saudi Pharm J 2015;23(1):67-74.

8. Madan JR, Ghuge NP, Dua K. Formulation and evaluation of proniosomes containing lornoxicam. Drug Deliv Transl Res 2016;6(5):511-8.

9. $\mathrm{Hu} \mathrm{C}$, Rhodes DG. Proniosomes: A novel drug carrier preparation. Int J Pharm 1999;185(1):23-35.

10. Debnath A, Kumar A. Structural and functional significance of niosome and proniosome in drug delivery system. Int J Pharm Eng 2015;3(3):621-37.

11. Vardhani $\mathrm{CH}$, Nirosha M, Chandrasekhar KB. Proniosomal gel: An effective approach for topical and transdermal drug delivery. Int J Res Pharm Sci 2016;7(2):179-83.

12. Pardakhty A, Moazeni E. Nano-niosomes in drug, vaccine and gene delivery: A rapid overview. Nanomed J 2013;1(1):1-12.
13. Sabareesh M, Khan PR, Sudheer B. Formulation and evaluation of lisinopril dihydrate transdermal proniosomal gels. J Appl Pharm Sci 2011;1(8):181-5.

14. Nagasamy D, Swetha V, Tulasi K, Kalyani K. Proniosomes: A Superior Drug Delivery System. Int J Pharm Sci Drug Res 2014;6(3):178-82.

15. Sulthana AA, George BJ, Samuel J, Thomas N, Daisy PA, Carla B. Proniosomes: A future revolutionary drug delivery system. Int J Pharm Chem Biol Sci 2015;5(4):879-82.

16. Walve JR, Rane BR, Gujrathi NA, Bakaliwal SR, Pawar SP. Proniosomes: A surrogated carrier for improved transdermal drug delivery system. Int J Res Ayurveda Pharm 2011;2(3):74350 .

17. Khatoon M, Shah KU, Din FU, Shah SU, Rehman AU, Dilawar $\mathrm{N}$, et al. Proniosomes derived niosomes: Recent advancements in drug delivery and targeting. Drug Deliv 2017;24(2):56-69.

18. Touitou E, Junginger HE, Weiner ND, Nagai T, Mezei M. Liposomes as carriers for topical and transdermal delivery. J Pharm Sci 1994;83(9):1189-203.

19. Sinico C, Fadda AM. Vesicular carriers for dermal drug delivery. Expert Opin Drug Deliv 2009;6(8):813-25.

20. Junginger HE, Hofland HJ, Bouwstra JA. Liposomes and niosomes: Interactions with human skin. Cosmet Toilet 1991;106(8):45-50.

21. Malarkodi A, Shrilakshmi S. Proniosomal gel: An effective novel therapeautic topical drug delivery system. Int J Pharm Tech Res 2013;5(4):1754-64.

22. Blazek-Welsh AI, Rhodes DG. Maltodextrin-based proniosomes. AAPS Pharm Sci 2001;3(1):1-8.

23. Blazek-Welsh AI, Rhodes DG. SEM imaging predicts quality of niosomes from maltodextrin-based proniosomes. Pharm Res 2001;18(5):656-61.

24. Mahdi J, Effionora A, Joshita D. Preparation of Maltodextrin DE 5-10 based ibuprofen Proniosomes. Maj Ilmu Kefarmasian 2004; 1:10-20.

25. Solanki AB, Parikh JR, Parikh RH. Formulation and optimization of piroxicam proniosomes by 3-factor, 3-level Box-Behnken design. AAPS Pharm Sci Tech 2007;8(4):43-9.

26. Ramesh YV, Jawahar N, Jakki SL. Proniosomes: A novel nano vesicular transdermal drug delivery. J Pharm Sci Res 2013;5(8):153-8.

27. IAAttia, SA EL-Gizawy, MA Fouda, AM Donia. Influence of a niosomal formulation on the oral bioavailability of acyclovir in rabbits. AAPS Pharm Sci Tech 2007;8(4):206-12.

28. Jadon PS, Gajbhiye V, Jadon RS, Gajbhiye KR, Ganesh N. Enhanced oral bioavailability of griseofulvin via niosomes. AAPS Pharm Sci Tech 2009;10(4):1186-92.

29. Kumar GP, Rajeshwarrao P. Nonionic surfactant vesicular systems for effective drug delivery: An overview. Acta Pharm Sin B 2011;1(4):208-19.

30. Kamboj S, Saini V, Bala S. Formulation and characterization of drug loaded nonionic surfactant vesicles (niosomes) for oral bioavailability enhancement. Sci World J 2014;959741;1-8.

31. Yadav K, Yadav D, Saroha K, Nanda S, Mathur P, Syan N. Proniosomal Gel: A provesicular approach for transdermal drug delivery. Der Pharm Lett 2010;2(4):189-98.

32. Lithaa T, Shomaa J, Viswanada V. Provesicular niosomes gel: A novel absorption modulator for transdermal delivery. Int $\mathbf{J}$ Drug Dev Res 2011;3(3):58-69.

33. Fang JY, Yu SY, Wu PC, Huang YB, Tsai YH. In vitro skin permeation of estradiol from various proniosome formulations. Int J Pharm 2001;215(1-2):91-9.

34. Vora B, Khopade AJ, Jain NK. Proniosomes based transdermal 
delivery of levonorgesterel for effective contraception. J Control Release 1998;54(2):149-65.

35. Sharma A, Gupta NK, Dixit VK. Complexation with phosphatidyl choline as a strategy for absorption enhancement of boswellic acid. Drug Deliv 2010;17(8):587-95.

36. Rogerson AC, Cummings J, Willmott N, Florence AT. The distribution of doxorubicin in mice following administration in niosomes. J Pharm Pharmacol 1988;40(5):337-42.

37. Ge X, Wei M, He S, Yuan WE. Advances of non-ionic surfactant vesicles (niosomes) and their application in drug delivery. Pharmaceutics 2019;11(2):55.

38. Gupta A, Prajapati SK, Balamurugan M, Singh M, Bhatia D. Design and development of a proniosomal transdermal drug delivery system for captopril. Trop J Pharma Res 2007;6(2):687-93.

39. Sankar V, Ruckmani K, Durga S, Jailani S. Proniosomes as drug carriers. Pak J Pharm Sci 2010;23(1):103-7.

40. Rahimpour Y, Kouhsoltani M, Hamishehkar H. Proniosomes in transdermal drug delivery. Curr Pharm Des 2015;21(20):288391.

41. Perrett S, Golding M, Williams WP. A simple method for the preparation of liposomes for pharmaceutical applications: characterization of the liposomes. J Pharm Pharmacol 1991;43(3):154-61.

42. Muzzalupo R. Niosomes and proniosomes for enhanced skin delivery. In: Percutaneous penetration enhancers chemical methods in penetration enhancement 2016;147-60.

43. Singh S, Chaudhari Y, Singh R, Kunwarpuriya A. Proniosomes: A recent advancement in vesicular drug delivery system. World J Pharma Res 2015;4:1671-89.

44. Ahmad MZ, Mohammed AA, Mokhtar Ibrahim M. Technology overview and drug delivery application of proniosome. Pharm Dev Technol 2017;22(3):302-11.

45. Gregoriadis G, Florence A. Liposomes in drug delivery, Clinical, diagnostic and ophthalmic potential characteristics with p-aminobenzoic acid and isosorbide dinitrate as model drugs. J Pharm Sci 1993;80:1153-6.

46. Khoee S, Yaghoobian M. Niosomes: A novel approach in modern drug delivery systems. In: Nanostructures for drug delivery 2017;207-37.

47. Bachhav AA. Proniosome: A novel non-ionic provesicules as potential drug carrier. Asian J Pharm 2016;10(3):S210-S222.

48. Muzzalupo R, Tavano L, Cassano R, Trombino S, Ferrarelli T, Picci N. A new approach for the evaluation of niosomes as effective transdermal drug delivery systems. Eur J Pharm Biopharm 2011;79(1):28-35.

49. El-Enin AS, Khalifa MK, Dawaba AM, Dawaba HM. Proniosomal gel-mediated topical delivery of fluconazole: Development, in vitro characterization and microbiological evaluation. J Adv Pharm Technol Res 2019;10(1):20-6.

50. Murthy GK, Kishore S. Formulation and evaluation of transdermal gels of diltiazem hydrochloride. Indian J Pharm Educ Res 2008;42(3):272-6.

51. Selvamani V. Stability studies on nanomaterials used in drugs. In: Characterization and biology of nanomaterials for drug delivery 2019;425-44.

52. Honary S, Zahir F. Effect of zeta potential on the properties of nano-drug delivery systems-A review (Part 1). Trop J Pharm Res 2013;12(2):255-64.

53. Emad Eldeeb A, Salah S, Ghorab M. Proniosomal gelderived niosomes: An approach to sustain and improve the ocular delivery of brimonidine tartrate; formulation, in vitro characterization and in vivo pharmacodynamic study. Drug
Deliv 2019;26(1):509-21.

54. Ramkanth S, Chetty CM, Sudhakar Y, Thiruvengadarajan VS, Anitha P, Gopinath C. Development, characterization and in vivo evaluation of proniosomal based transdermal delivery system of atenolol. Future J Pharm Sci 2018;4(1):80-7.

55. Shah J, Nair AB, Shah H, Jacob S, Shehata TM, Morsy MA. Enhancement in antinociceptive and anti-inflammatory effects of tramadol by transdermal proniosome gel. Asian J Pharm Sci 2020;15(6):786-96.

56. Lather V, Sharma D, Pandita D. Proniosomal gel-mediated transdermal delivery of bromocriptine: In vitro and ex vivo evaluation. J Exp Nanosci 2016;11(13):1044-57.

57. Sambhakar S, Paliwal S, Sharma S, Singh B. Formulation of risperidone loaded proniosomes for effective transdermal delivery: An in vitro and in vivo study. Bull Fac Pharm Cairo Univ 2017;55(4):239-47.

58. Radha GV, Rani TS, Sarvani B. A review on proniosomal drug delivery system for targeted drug action. J Basic Clin Pharm 2013;4(2):42-8.

59. Khalil RM, Abdelbary GA, Basha M, Awad GE, El-Hashemy HA. Design and evaluation of proniosomes as a carrier for ocular delivery of lomefloxacin $\mathrm{HCl}$. J Liposome Res 2017;27(2):118-29.

60. Maurer JK, Li HF, Petroll WM, Parker RD, Cavanagh HD, Jester JV. Confocal microscopic characterization of initial corneal changes of surfactant-induced eye irritation in the rabbit. Toxicol Appl Pharmacol 1997;143(2):291-300.

61. Maiti S, Paul S, Mondol R, Ray S, Sa B. Nanovesicular formulation of brimonidine tartrate for the management of glaucoma: In vitro and in vivo evaluation. AAPS Pharm Sci Tech 2011;12(2):755-63.

62. Hofland HE, Bouwstra JA, Verhoef JC, Buckton G, Chowdry BZ, Ponec M, et al. Safety aspects of non-ionic surfactant vesicles: A toxicity study related to the physicochemical characteristics of non-ionic surfactants. J Pharm Pharmacol 1992;44(4):287-94.

63. Hait SK, Moulik SP. Determination of Critical Micelle Concentration (CMC) of nonionic surfactants by donoracceptor interaction with lodine and correlation of CMC with hydrophile-lipophile balance and other parameters of the surfactants. J Surfactants Deterg 2001;4(3):303-9.

64. Soliman SM, Abdelmalak NS, El-Gazayerly ON, Abdelaziz N. Novel non-ionic surfactant proniosomes for transdermal delivery of lacidipine: Optimization using 23 factorial design and in vivo evaluation in rabbits. Drug Deliv 2016;23(5):160822.

65. Babita, Bhoop, Singh B, Katare, Prakash O. Development of optimized lipid based nanostructured drug delivery systems of darunavir and lopinavir for improved bioavailability and biodistribution. Shodhganga 2016.

66. Topical drug delivery with lipid excipients. Gattefosse 2019.

67. Kumar YA, Setty CM. Formulation and evaluation of maltodextrin based doxorubicin $\mathrm{HCl}$ proniosomes. Res J Pharm Technol 2019;12(6):2776-80.

68. Shah H, Nair AB, Shah J, Bharadia P, Al-Dhubiab BE. Proniosomal gel for transdermal delivery of lornoxicam: Optimization using factorial design and in vivo evaluation in rats. Daru J Pharm Sci 2019;27(1):59-70.

69. Chauhan SB, Naved T, Parvez N. Formulation development and evaluation of proniosomal gel of ethinylestradiol and levonorgestrel for antifertility treatment. Asian J Pharm Clin Res 2019;12(1):364-8.

70. Sohail MF, Shahnaz G, ur Rehman F, ur Rehman A, Ullah 
$\mathrm{N}$, Amin U, et al. Development and evaluation of optimized thiolated chitosan proniosomal gel containing duloxetine for intranasal delivery. AAPS Pharm Sci Tech 2019;20(7):288.

71. Shete A, Thorat P, Doijad R, Sajane S. Formulation and in vitro, in vivo evaluation of proniosomal gel of neomycin sulphate. Int J Appl Pharm 2019:156-63.

72. Sammour RM, Taher M, Chatterjee B, Shahiwala A, Mahmood S. Optimization of aceclofenac proniosomes by using different carriers, Part 1: Development and characterization. Pharmaceutics 2019;11(7):350.

73. Rao M, Kamble P. Formulation and evaluation of antifungal proniosomal gel for oral candidiasis. J Drug Deliv Ther 2018;8(4):291-301.

74. Radha GV, Sastri KT, Prathyusha P, Bhanu P, Rajkumar J. Formulation and evaluation of aceclofenac proniosome loaded orabase for management of dental pain. Int J Appl Pharm 2018;10(7):204-10.

75. Ahmed M, SamyAfaf A, Ramadan Amal SM, Abu EE, Yasmin IM Mortagi. Formulation and Optimization of Itraconazole Proniosomes using box behnken design. Int J Appl Pharm 2018;10(2):41-51.
76. Soujanya C, Ravi Prakash P. Formulation and evaluation of proniosomal gel-based transdermal delivery of atorvastatin calcium by box-behnken design. Asian J Pharm Clin Res 2019;12:335-43.

77. Ravi GS, Dubey A, Hebbar S. Development of maltodextrin based proniosomes derived niosomes of Ofloxacin. Int J Pharm Sci Res 2019;10(3):1485-90.

78. Fouda NH, Abdelrehim RT, Hegazy DA, Habib BA. Sustained ocular delivery of Dorzolamide- $\mathrm{HCl}$ via proniosomal gel formulation: In vitro characterization, statistical optimization and in vivo pharmacodynamic evaluation in rabbits. Drug Deliv 2018;25(1):1340-9.

79. Qiang L, Xiao J, Li L, Hongxia H, Shasha L, Bin Z. Formulation of paeonol proniosomes and preparing method thereof. Chinese Patent 103340823B;2015.

80. Krauss-Etschmann S, Hartmann A, Schmitt-Kopplin P, Schloter M. Methods and compositions for treating inflammatory diseases. United States Patent 20190083461A1;2019.

81. Umberto di Maio. Pharmaceutical composition for the prevention and/or treatment of cardiovascular and osteoarticular diseases. WIPO (PCT) WO2019038316A1;2017.. 